\title{
APPLICATION OF CULTURE-BASED, MASS SPECTROMETRY AND MOLECULAR METHODS TO THE STUDY OF GUT MICROBIOTA IN CHILDREN
}

\author{
Efimov BA $\bowtie$, Chaplin AV, Sokolova SR, Chernaia ZA, Pikina AP, Savilova AM, Kafarskaya LI
}

Pirogov Russian National Research Medical University, Moscow, Russia

In recent decades, nucleic acid sequencing technologies used for metagenomic analysis have become the main methods for assessing the composition of microbiota. At the same time, the use of novel methods of cultivation and identification of microorganisms in microbiological research led to the renaissance of culture-based technologies, because facilitated the discovery and isolation of both new strains of well-known microorganisms as well as uncultivated and unexplored bacterial taxa. The aim of this study was to evaluate the potential of using the culture-based method for the assessment of the qualitative and quantitative composition of the intestinal microbiota in healthy children. Eleven growth media were inoculated with serial dilutions of stool samples in order to analyze the profile of dominant anaerobic bacteria, as well as aerobic bacteria and fungi in 20 healthy children aged 2-4 years. The identification of microorganisms was performed using MALDI TOF MS and 16S rRNA gene fragment sequencing were used. 1,819 isolated and identified strains belong to 7 phyla, 13 classes, 18 orders, 33 families, 77 genera and 149 species in the Bacteria domain. The Bacteroidetes, Firmicutes, Actinobacteria and Proteobacteria phyla were most abundant and frequent. The greatest species diversity (more than 85 species) was found in the Firmicutes phylum. Ten new previously uncharacterized bacterial strains were isolated.

Keywords: gastrointestinal tract microbiota, children, isolation and purification of bacteria, biodiversity, microbiological techniques/methods, DNA sequencing, mass spectrometry, Matrix-Assisted Laser Desorption-lonization

Funding: the study was supported by Russian Science Foundation (research grant № 17-15-01488).

Author contribution: Efimov BA - research planning, literature analysis, screening children, specimen collection, microbiological research, mass spectrometry research, analysis and interpretation of data, preparing a draft manuscript; Chaplin AV — research planning, literature analysis, isolation of bacterial DNA, carrying out PCR, amplicons purification for sequencing, data analysis and interpretation, preparing a draft manuscript; Sokolova SR - research planning, literature analysis, specimen collection, microbiological research, isolation of bacterial DNA, carrying out PCR, amplicons purification for sequencing, data analysis and interpretation preparing a draft manuscript; Chernaia ZA — research planning, literature analysis, microbiological research, mass spectrometry research, data analysis and interpretation, preparing a draft manuscript; Pikina AP — research planning, literature analysis, microbiological research, mass spectrometry research, data analysis and interpretation, preparing a draft manuscript; Savilova AM — literature analysis, microbiological research, preparing a draft manuscript; Kafarskaya LI — research planning, literature analysis, screening children, microbiological research, analysis and interpretation of data, preparing a draft manuscript.

Compliance with ethical standards: the study was approved by the Ethics Committee of Pirogov Russian National Research Medical University (protocol № 165 of May 22, 2017). The parents of children participants signed a voluntary informed consent to participate in the study.

$\triangle$ Correspondence should be addressed: Boris A. Efimov

Ostrovityanova 1, Moscow, 117997; efimov_ba@mail.ru

Received: 27.06.2019 Accepted: 12.07.2019 Published online: 09.08.2019

DOI: $10.24075 /$ brsmu.2019.048

\section{ОПЫТ ПРИМЕНЕНИЯ КУЛЬТУРАЛЬНОГО, МАСС-СПЕКТРОМЕТРИЧЕСКОГО И МОЛЕКУЛЯРНОГО МЕТОДОВ В ИССЛЕДОВАНИИ КИШЕЧНОЙ МИКРОБИОТЫ У ДЕТЕЙ}

\author{
Б. А. Ефимов $\bowtie$, А. В. Чаплин, С. Р. Соколова, З. А. Черная, А. П. Пикина, А. М. Савилова, Л. И. Кафарская
}

Российский национальный исследовательский медицинский университет имени Н. И. Пирогова, Москва, Россия

\begin{abstract}
В последние десятилетия основными методами оценки состава микробиоты стали технологии секвенирования нуклеиновых кислот, используемые для метагеномного анализа. В то же время внедрение в практику микробиологических исследований новых методов культивирования и идентификации микроорганизмов привело к ренессансу культуральных технологий, поскольку позволило решить задачи по поиску и выделению новых штаммов как уже известных микроорганизмов, так и ранее некультивируемых и неизученных бактериальных таксонов. Целью работы было оценить потенциал использования культурального метода для оценки качественного и количественного состава кишечной микробиоты здоровых детей. Анализ состава доминирующих групп анаэробных бактерий, а также аэробных бактерий и грибов у 20 здоровых детей в возрасте 2-4 лет проводили путем высева серийных разведений фекалий на 11 питательных сред. Для идентификации микроорганизмов использовали метод MALDI TOF MS и секвенирование фрагмента гена 16S pPHK. Идентификация 1819 выделенных штаммов микроорганизмов показала, что они принадлежали к 7 типам, 13 классам, 18 порядкам, 33 семействам, 77 родам и 149 видам домена бактерий. По количеству и частоте встречаемости доминировали бактерии типов Васtеroidetes, Firmicutes, Actinobacteria и Proteobacteria. Наибольшее видовое разнообразие (более 85 видов) обнаружено среди бактерий типа Firmicutes. Выделено 10 штаммов новых, пока не охарактеризованных бактериальных видов.
\end{abstract}

Ключевые слова: микробиота кишечника, дети, выделение бактерий, биоразнообразие, микробиологические методы, секвенирование ДНК, массспектрометрия, MALDI TOF MS

Финансирование: работа поддержана грантом Российского научного фонда (№ 17-15-01488).

Информация о вкладе авторов: Б. А. Ефимов - планирование исследования, анализ литературы, отбор обследуемых детей, сбор биоматериала, микробиологическое исследование, спектрометрическое исследование, анализ и интерпретация данных, подготовка черновика рукописи; А. В. Чаплин планирование исследования, анализ литературы, выделение бактериальной ДНК, проведение ПЦР, очистка ампликонов для секвенирования, анализ и интерпретация данных, подготовка черновика рукописи; С. Р. Соколова - планирование исследования, анализ литературы, сбор биоматериала, микробиологическое исследование, выделение бактериальной ДНК, проведение ПЦР, очистка ампликонов для секвенирования, анализ и интерпретация данных, подготовка черновика рукописи; 3. А. Черная - планирование исследования, анализ литературы, микробиологическое исследование, спектрометрическое исследование, анализ и интерпретация данных, подготовка черновика рукописи; А. П. Пикина - планирование исследования, анализ литературы, микробиологическое исследование, спектрометрическое исследование, анализ и интерпретация данных, подготовка черновика рукописи; А. М. Савилова - анализ литературы, микробиологическое исследование, подготовка черновика рукописи; Л. И. Кафарская планирование исследования, анализ литературы, отбор обследуемых детей, микробиологическое исследование, анализ и интерпретация данных, подготовка черновика рукописи.

Соблюдение этических стандартов: исследование было одобрено этическим комитетом РНИМУ имени Н. И. Пирогова (протокол № 165 от 22 мая 2017 г.). Родители каждого ребенка подписали добровольное информированное согласие на участие в исследовании.

$\varangle$ Для корреспонденции: Борис Алексеевич Ефимов ул. Островитянова, д. 1, г. Москва, 117997; efimov_ba@mail.ru

Статья получена: 27.06.2019 Статья принята к печати: 12.07.2019 Опубликована онлайн: 09.08.2019 DOI: $10.24075 /$ vrgmu.2019.048 
Most representatives of human and animal intestinal microbiome are classified as difficult-to-cultivate or nonculturable groups of microorganisms. Currently, massive parallel sequencing of DNA samples is used predominantly for the assessment of the composition of gut microbiota, for example, sequencing of the fragments of genes encoding 16S rRNA or sequencing of genomic DNA fragments [1, 2]. However, it is often difficult to interpret the obtained data, since the analyzed nucleotide sequences sometimes cannot be correlated with known bacteria or bacteriophages [3-5]. These approaches also have a disadvantage: only the relative ratio of the dominant groups of bacteria can be characterized efficiently, while the exact number of dominant or minor taxa remains beyond such studies $[6,7]$ Real-time PCR with species-specific or group-specific primers and subsequent normalization of the results using recombinant plasmid DNA containing the cloned regions of amplified gene fragments are used for more accurate quantitative determination of bacteria [8]. However, this method makes it possible to determine the total number of copies of amplified DNA regions in the sample rather than the number of viable bacterial cells. In addition, due to the complexity of the method, especially in the studies aimed at quantification of the wide range of microorganisms, this approach is mainly used to analyze the composition of large taxonomic clusters of microorganisms (genera, families, groups) rather than certain known species. Thus, along with the development of technologies based on the sequencing of the genetic material of microorganisms, it is still important to improve cultural methods, since it allows us to solve the problem of searching for, isolating, determining the number and studying the biological properties of new strains in well-known bacteria, as well as in unexplored bacterial taxa [9].

The aim of the study was to evaluate the potential of using the culture-based method to assess the qualitative and quantitative composition of the intestinal microbiota of healthy children by stool samples inoculation of growth media widely used in laboratory practice for fastidious bacteria.

\section{METHODS}

The study of the parameters of colon microbial colonization was carried out in a group of 20 healthy children of both sexes living in Moscow. 17 of them regularly attended preschool institutions, and three children were in home schooling. Children were selected by the authors of the study. The age of the subjects ranged from 2 years 11 months to 4 years 10 months (average age 3 years 5 months), of which there were 12 boys and 8 girls. Inclusion criteria: children of both genders; children's age 2.5-4 years; parental consent presence. Exclusion criteria: children of other age; the presence of any chronic disease, such as diabetes mellitus, bronchial asthma, gastrointestinal diseases (celiac disease, functional constipation, short bowel syndrome, or inflammatory bowel disease); the presence of food allergies or parental belief in lactose intolerance in a child; pronounced selectivity in food consumption; use of antibiotics, immunomodulatory, steroid or probiotic drugs for 6 months before the study; infectious gastroenteritis in the last 6 months before the study, confirmed by laboratory tests; history of gastrointestinal surgery.

The material for the study was the feces of children which were collected by the parents with a sterile spatula and placed in a sterile container for transportation. The study was carried out under the condition that the amount of material placed in a container was not less than $15 \mathrm{~g}$, and the time of its delivery to the laboratory did not exceed 2 hours from the moment of collection. In the laboratory immediately after receiving the feces were homogenized, their tenfold serial dilutions (from 10 to $10^{9}$ times) were prepared in test tubes with sterile Schaedler Anaerobe Broth liquid medium (Oxoid, Basingstoke; UK), and aliquots in a volume of $0.1 \mathrm{ml}$ of the corresponding dilutions were inoculated on Petri plates with growth media. The isolation of strictly anaerobic bacteria was performed on the Schaedler Anaerobe Agar (Oxoid, Basingstoke; UK) with the addition of $5 \%(\mathrm{v} / \mathrm{v})$ defibrinated sheep blood, Anaerobe Basal Agar (Oxoid, Basingstoke; UK) with the addition of sheep blood, Columbia Agar (bioMérieux, Marcy I'Etoile; France) with the addition of sheep blood. Inoculation of growth media was carried out from the $10^{7}, 10^{8}$, and $10^{9}$ fold dilutions of the sample. Bifidobacteria and sulfate-reducing bacteria were also isolated on the Bifidobacterium Agar (Himedia Labs Inc.; India) and Perfringens Agar Base (Himedia Labs Inc.; India) respectively from the specimen $10^{5}, 10^{7}$ and $10^{8}$ fold dilutions. The Petri dishes were incubated in the anaerobic jars (Schutt Labortechnik $\mathrm{GmbH}$; Germany) filled with a gas mixture (85\% $\mathrm{N}_{2}, 10 \% \mathrm{H}_{2}, 5 \% \mathrm{CO}_{2}$ ) in the presence of platinum catalysts at $37^{\circ} \mathrm{C}$ for 72 hours. Lactic acid bacteria were cultured on Lactobacillus MRS Agar medium (Himedia Labs Inc.; India) from the specimen $10^{3}$ and $10^{5}$ fold dilutions, the plates were incubated in the anaerobic jars (GasPak; USA) with the 7\% $\mathrm{CO}_{2}$ atmosphere for 48 hours. Aerobic bacteria were isolated from the sample $10,10^{3}, 10^{5}$ and $10^{7}$ fold dilutions on the following media: Endo Agar (Becton Dickinson and Company, USA), Salmonella-Shigella-Agar (bioMerieux Marcy I'Etoile; France), Gelatin Mannitol Salt Agar (Staphylococcus Agar \# 110, Himedia Labs Inc.; India), m-Enterococcus Agar (Difco Laboratories, Franklin Lakes; USA), Columbia Agar (bioMérieux, Marcy I'Etoile; France) with the addition of 5\% (v/v) sheep blood. The Sabouraud Chloramphenicol 2 Agar medium (bioMérieux, Marcy I'Etoile; France) was used to isolate the fungi.

After incubation the culture properties of bacteria were described, morphological types were counted separately for each colony type. In addition, bacteria from each type of colonies were stained by Gram method, subcultured on plates with the same medium and incubated under anaerobic or aerobic conditions to obtain the stock of bacteria for identification and preservation. Partially, the isolated microorganism strains were lyophilized after freezing in a $10 \%$ sucrose/1\% gelatin $(\mathrm{w} / \mathrm{v})$ solution in the Freeze Dryer SB1 (Chemlab; UK). Test tubes with lyophilized strains of microorganisms were stored at a temperature of $-80^{\circ} \mathrm{C}$.

The primary identification of bacteria and fungi was performed using the MALDI TOF mass spectrometry on the Vitek MS Plus unit (bioMérieux; France) with the Saramis Premium v. 4.10 software according to the manufacturer's recommendations $[10,11]$. The strains of bacteria, the species identity of which could not be established using MALDI-TOF mass spectrometry, were identified by $16 \mathrm{~S}$ rRNA gene sequencing $[12,13]$. In addition, $16 \mathrm{~S}$ rRNA gene sequencing was used for some strains to confirm the results of species identification by mass spectrometry. The polymerase chain reaction (PCR) amplified a portion of the 16S rRNA gene using the universal bacterial primers 27F (5'-AGAGTTTGATCCTGGCTCAG-3') and 1492R (5'-ACGGYTACCTTGTTACGACTT-3') for 35 cycles with the following program: denaturation $20 \mathrm{~s}$ at $94^{\circ} \mathrm{C}$; primer annealing $20 \mathrm{~s}$ at $58^{\circ} \mathrm{C}$; elongation $90 \mathrm{~s}$ at $72^{\circ} \mathrm{C}$. The obtained PCR product was purified using the Cleanup Standard kit (Evrogen; Russia). The Sanger sequencing of the amplified DNA fragment from the UF1 primer was carried out at Evrogen (Evrogen; Russia). The determination of the cut-off boundaries 
of the sequences by the quality of electrophoregrams was carried out visually using the Chromas Lite software (version 2.6.6, Technelysium Pty. Ltd.; Australia). The species of bacteria was determined on the basis of a search for the nucleotide sequences obtained in the GenBank database using the Megablast algorithm. The result of the comparison was considered to correspond to the level of the species in the case when its partially sequenced $16 \mathrm{~S}$ rRNA gene sequence resembled $\geq 98.7 \%$ of the sequence of the closest known bacterial species in the GenBank database [14].

The number of bacteria was expressed in $\log _{10}$ colony forming units in $1 \mathrm{~g}$ of the test material $\left(\log _{10} \mathrm{CFU} / \mathrm{g}\right)$. The $\mathrm{CFU} / \mathrm{g}$ of the test material was calculated using the following formula: $\mathrm{CFU} / \mathrm{g}=$ the number of colonies of the corresponding type of microorganisms grown on the plate (or the average number of colonies of the corresponding type of microorganisms, in cases when bacteria of one type gave growth on different media or gave growth only on one of growth media, but were determined at more than one dilution) $\times 10 \times$ dilution ratio. The total number of cultured microorganisms per sample was calculated by adding the quantitative values of individual species.

Statistical data processing was performed using the Mann-Whitney test and Fisher's exact test, multiple comparisons were corrected using the Bonferroni method. The tendency to form clusters was checked using the VAT algorithm [15] and the principal component analysis.

\section{RESULTS}

In total, 1,819 strains of microorganisms were isolated from 20 healthy children. The species identification of most strains was carried out using the MALDI TOF MS. To establish the taxonomic identity of 140 bacterial strains that could not be identified by mass spectrometry 16S rRNA gene sequencing was performed. Comparative analysis of the obtained nucleotide sequences with the GenBank database showed that 130 bacterial strains belonged to 88 known species, and 10 belonged to new, not yet studied bacterial taxa. The number of identified microorganism species per sample varied from 21 to 48 and averaged $34 \pm 8$. The total number of viable bacteria per $1 \mathrm{~g}$ of faeces varied from 10.0 to $11.1 \log _{10} \mathrm{CFU} / \mathrm{g}$ and averaged $10.6 \pm 0.4 \log _{10} \mathrm{CFU} / \mathrm{g}$.

In general, it was found that the isolated strains belonged to 7 phyla, 13 classes, 18 orders, 33 families, 77 genera, and 149 species of the Bacteria domain. Also 3 species of fungi from 2 families of the Saccharomycetales order were identified.

The reduction in the dimension by principal component analysis, as well as the use of the VAT algorithm, did not reveal a tendency to form clusters from the microbiocenoses of the examined children on the basis of the obtained data on the quantitative and qualitative composition, which does not allow classifying the microbiocenoses in this study into enterotypes or their analogs. There were no statistically significant differences in the microbial composition of the gut tract microbiota, depending on the age and gender of children, which may be due to the small size and homogeneity of the sample.

Generic assignment, frequency of occurrence and the quantitative level of microorganisms isolated from feces of 20 healthy children are presented in tables 1-5. It was revealed that dominant by the number and frequency of occurrence bacteria belonged to the Firmicutes (9.8 $\left.\pm 0.4 \log _{10} \mathrm{CFU} / \mathrm{g}\right)$, Bacteroidetes (10.3 $\pm 0.4 \log _{10}$ CFU/g), Actinobacteria $\left(10.0 \pm 0.5 \log _{10} \mathrm{CFU} / \mathrm{g}\right)$, and Proteobacteria $\left(8.5 \pm 1.1 \log _{10} \mathrm{CFU} / \mathrm{g}\right)$ phyla. Representatives of each of these groups of bacteria were found in all children. In addition, in $25 \%$ of children (an average of $9.1 \pm 0.4 \log _{10}$ CFU/g) the bacteria of the Akkermansia muciniphila species were obtained in pure culture, which belong to the Verrucomicrobia phylum, in two children the Fusobacterium mortiferum (8.8 and $8.6 \log _{10}$ CFU/g) were isolated which represent the Fusobacteria phylum. From one child the strain of the Victivallis vadensis bacteria belonging to the Lentisphaerae phylum was isolated, its concentration was $10^{9} \log _{10} \mathrm{CFU} / \mathrm{g}$.

The phylum Actinobacteria consisted of the two classes of bacteria: Actinobacteria and Coriobacteriia (Table 1). Bacteria of Actinobacteria class belonged to 4 orders and 4 families, the representatives of the Bifidobacteriaceae and Propionibacteriaceae families prevailed. Bifidobacteria (occurred in $100 \%$ of children), were the dominant microorganisms in the gut microbiota of healthy children. A total of 6 species of bifidobacteria were isolated, among them $B$. longum, B. bifidum, B. adolescentis, and bifidobacteria of the $B$. catenulatum/pseudocatenulatum group.

The Coriobacteria class was represented mostly by the families Coriobacteriaceae and Eggerthellaceae, the dominant species were Collinsella aerofaciens and Eggerthella lenta.

The phylum Bacteroidetes consisted of 5 bacteria families belonging to order Bacteroidales (Table 2). The Bacteroidaceae family was represented by single genus Bacteroides, to which the 14 identified species belong. The bacteroids were isolated in $100 \%$ of cases in average number $10.1 \pm 0.4 \log _{10} \mathrm{CFU} / \mathrm{g}$ of feces. Among bacteroids the B. dorei/vulgatus and B. ovatus/ xylanisolvens species dominated in healthy children, as well as $B$. uniformis, $B$. fragilis and $B$. thetaiotaomicron.

The Rikenellaceae family was also represented by only one genus Alistipes and 9 isolated species. Alistipes occurred in $90 \%$ of healthy children. The average number of bacteria was $9.5 \pm 0.4 \log _{10} \mathrm{CFU} / \mathrm{g}$, the dominating species were A. onderdonkii, $A$. putredinis and $A$. finegoldii.

The Porphyromonadaceae family bacteria were isolated from $75 \%$ of children, they belonged to the Parabacteroides, Barnesiella and Coprobacter genera. The dominant species of these taxa were P.distasonis, P. merdae and B. intestinihominis observed in $45 \%, 35 \%$ and $40 \%$ of children respectively. Moreover, in almost all cases when bacteria of these taxonomic groups were detected, their concentration in the specimen was equal to or was close to $10^{9} \mathrm{CFU} / \mathrm{g}$.

Bacteria of the Prevotellaceae family turned out to be the rarest representatives of the order Bacteroidales at the used threshold for the detection of anaerobic bacteria, which was at least $10^{8}$ microbial cells per $1 \mathrm{~g}$ of feces. In total from three children (15\%) 5 strains of bacteria belonging to the Prevotella copri, P. melaninogenica, P. rara and Paraprevotella clara species were isolated.

The phylum Firmicutes demonstrated the greatest diversity of taxa, it was represented by 4 classes of bacteria, including 7 orders, 17 families, 45 genera, and 93 species of microorganisms, including new bacterial taxa found in this study (Table 3). Class Clostridia was represented only by the order Clostridiales, which included 47 species of bacteria belonging to 30 genera and 6 families. Representatives of the Lachnospiraceae family were found in $85 \%$ of children in average concentration of $9.0 \pm 1.0 \log _{10} \mathrm{CFU} / \mathrm{g}$ and were the most common taxon of this class. Among the bacteria species belonging to this family and found more often than others, was Clostridium clostridioforme, observed in 55\% of children at an average concentration of $8.2 \pm 1.0 \log _{10}$ CFU/g. The other common genera of the family Lachnospiraceae were Blautia (in $65 \%$ of children, average concentration $8.9 \pm 0.9 \log _{10} \mathrm{CFU} / \mathrm{g}$ ), as well as bacteria belonging to the 
Table 1. Species identity of the Actinobacteria phylum cultured bacteria of the gastrointestinal tract microflora isolated from healthy children $(n=20)$

\begin{tabular}{|c|c|c|c|}
\hline \multicolumn{4}{|c|}{ Phylum Actinobacteria } \\
\hline \multicolumn{4}{|c|}{ Class Actinobacteria } \\
\hline Taxa & Observed number $(\%)^{a}$ & Mean $\pm \mathrm{SD} \log _{10} \mathrm{CFU} / \mathrm{g}^{\mathrm{b}}$ & Growth media $^{e}$ \\
\hline $\begin{array}{l}\text { Order Bifidobacteriales, family Bifidobacteriaceae, } \\
\text { genus Bifidoibacterium }\end{array}$ & $20(100)$ & $9.8 \pm 0.6$ & \\
\hline Bifidobacterium longum & $20(100)$ & $9.3 \pm 0.5$ & SAA; ABA; CA; BA \\
\hline Bifidobacterium adolescentis & $8(40)$ & $9.5 \pm 0.6$ & SAA; ABA; CA; BA \\
\hline Bifidobacterium catenulatum/pseudocatenulatum ${ }^{c}$ & $11(55)$ & $9.1 \pm 0.7$ & SAA; ABA; CA; BA \\
\hline Bifidobacterium bifidum & $8(40)$ & $9.5 \pm 0.6$ & SAA; ABA; CA; BA \\
\hline Bifidobacterium animalis & $6(30)$ & $9.3 \pm 0.7$ & SAA; ABA; CA; BA \\
\hline Bifidobacterium breve & $2(10)$ & $9-10.2^{d}$ & SAA; ABA; BA \\
\hline $\begin{array}{l}\text { Order Propionibacteriales, family Propionibacteriaceae, } \\
\text { genus Cutibacterium }\end{array}$ & 7 (35) & $9.1 \pm 0.6$ & \\
\hline Cutibacterium acnes & $5(25)$ & $8.9 \pm 0.7$ & SAA; ABA; BA \\
\hline Cutibacterium granulosum & $2(10)$ & $9-9.8$ & ABA; CA \\
\hline \multicolumn{4}{|c|}{ Class Coriobacteriia } \\
\hline \multicolumn{4}{|l|}{ Order Coriobacteriales, family Coriobacteriaceae } \\
\hline Collinsella aerofaciens & $11(55)$ & $9.2 \pm 0.7$ & SAA; ABA; CA; BA \\
\hline \multicolumn{4}{|l|}{ Genus Eggerthellales, family Eggerthellaceae } \\
\hline Eggerthella lenta & $17(85)$ & $8.8 \pm 0.7$ & SAA; ABA; CA \\
\hline Gordonibacter pamelae & $3(15)$ & $8.5 \pm 0.9$ & $\mathrm{ABA} ; \mathrm{CA} ; \mathrm{PAB}$ \\
\hline Raoultibacter massiliensis & $1(5)$ & 9 & $\mathrm{CA}$ \\
\hline Slackia isoflavoniconvertens & $1(5)$ & 9.3 & CA \\
\hline Adlercreutzia equolifaciens & $1(5)$ & 9 & CA \\
\hline
\end{tabular}

Note (used in this table and tables 2-5): a Frequency of occurrence (absolute number of subjects/percentage of subjects); ${ }^{\mathrm{b}}$ Mean \pm standard deviation log ${ }_{10}$ of the number of viable microorganisms in $1 \mathrm{~g}$ of feces (CFU/g — colony forming units in $1 \mathrm{~g}$ of feces); ${ }^{\mathrm{c}} /{ }^{*}$ — A group of phylogenetically related microorganisms, identity was established using the MALDI TOF MS method on the Vitek MS Plus unit with the Saramis Premium V. 4.10 software; ${ }^{d}$ Smaller and larger value of the log ${ }_{10}$ index of the number of viable microorganisms, if they were found only in two examined children in the group; ${ }^{e}$ Names of the growth media used for isolation and registration of the relevant microorganisms types. SAA — Schaedler Anaerobe Agar; ABA — Anaerobe Basal Agar; CA — Columbia Agar; BA — Bifidobacterium Agar; PAB — Perfringens Agar Base; MRS — Lactobacillus MRS Agar; EA — Endo Agar; SSA — Salmonella-Shigella-Agar; GMSA — Gelatin Mannitol Salt Agar (Staphylococcus Agar \# 110); mEA — mEnterococcus Agar; CAa - Columbia Agar, plates with which were incubated aerobically; SC2A — Sabouraud Chloramphenicol 2 Agar.

genus Anaerostipes (in $40 \%$ of children, concentration $8.2 \pm$ $\left.1.0 \log _{10} \mathrm{CFU} / \mathrm{g}\right)$. Another common family of bacteria in the Clostridia class were the Ruminococcaceae representatives (in 65\% of children, average concentration $8.8 \pm 0.5 \log _{10} \mathrm{CFU} / \mathrm{g}$ ) mostly represented by the species Flavonifractor plautii, Ruthenibacterium lactatiformans and Anaerotruncus colihominis. It is worth noting that the bacteria of such species of the Ruminococcaceae family as Faecalibacterium prausnitzii and Gemmiger formicilis, which, according to the results of sequencing of the libraries of $16 \mathrm{~S}$ rRNA genes, constitute the dominant part of the normal human gastrointestinal tract microflora [16], were isolated only from one child. Such results indicate that it is necessary to use selective growth media and exclude the specimen contact with atmospheric oxygen, due to the extremely high sensitivity of these bacterial taxa to the latter. Another frequently detected taxon of the Firmicutes phylum were members of the Erysipelotrichaceae family (class Erysipelotrichia, order Erysipelotrichales), which were found in $55 \%$ of healthy children at an average concentration of $8.5 \pm 1.0 \log _{10} \mathrm{CFU} / \mathrm{g}$. Among 6 genera and 9 species of bacteria of this family, Clostridium innocuum and Clostridium ramosum dominated. They were detected with frequency equal to $40 \%$ in concentration exceeding $10^{8} \mathrm{CFU} / \mathrm{g}$.

Bacteria belonging to the Negativicutes class were present in $100 \%$ of children, the average concentration was $8.9 \pm 0.7 \log _{10}$ CFU/g. The dominant taxa of this group were representatives of the Veillonellaceae family, which included the bacteria of the genera Veillonella and Dialister (in 35\% and $45 \%$ of children respectively), as well as the family Acidaminococcaceae mainly represented by the Phascolarctobacterium faecium species, isolated in high concentrations from $40 \%$ of children.

Among colon bacteria belonging to the phylum Proteobacteria, representatives of the Betaproteobacteria, Deltaproteobacteria and Gammaproteobacteria classes were identified (Table 4). The Betaproteobacteria class included different bacteria species of the Sutterellaceae family (isolated from $60 \%$ of children, the average concentration $\left.8.8 \pm 0.4 \log _{10} \mathrm{CFU} / \mathrm{g}\right)$. The Deltaproteobacteria was mainly represented by the hydrogen sulfide forming bacteria of the Bilophila wadsworthia species (isolated from $55 \%$ of children, the average concentration $8.0 \pm 0.8 \log _{10} \mathrm{CFU} / \mathrm{g}$ ). Finally, the Gammaproteobacteria class was represented by only one family Enterobacteriaceae. Escherichia coli were determined in $100 \%$ of children at the average concentration of $7.2 \pm 0.4 \log _{10} \mathrm{CFU} / \mathrm{g}$. Other relatively frequently observed members of the family were bacterial species Enterobacter cloacae (30\%), Citrobacter freundii (20\%) and Klebsiella pneumoniae (20\%), their concentrations usually didn't exceed $10^{6} \mathrm{CFU} / \mathrm{g}$.

Fungi were found in $45 \%$ of healthy children in the amount of $3.4 \pm 1.4 \log _{10} \mathrm{CFU} / \mathrm{g}$, all of the isolated strains belonged to the order Saccharomycetales (Table 5). In the feces of $35 \%$ of the children, fungi of the genus Candida of the family Debaryomycetaceae were identified. They belong mainly to the C. albicans species. In addition, in two children fungi of the Clavispora lusitaniae species belonging to the Metschnikowiaceae family were present.

The taxonomic properties of 10 strains of bacteria which were isolated during this study and the species identity of 
Table 2. Species identity of the Firmicutes phylum cultured bacteria of the gastrointestinal tract microflora isolated from healthy children $(n=20)$

\begin{tabular}{|c|c|c|c|}
\hline \multicolumn{4}{|c|}{ Phylum Firmicutes } \\
\hline Taxa & Observed number (\%) & Mean \pm SD $\log _{10} \mathrm{CFU} / \mathrm{g}$ & Growth media \\
\hline \multicolumn{4}{|c|}{ Class Erysipelotrichia, order Erysipelotrichales } \\
\hline Family Erysipelotrichaceae & $11(55)$ & $8.5 \pm 1.0$ & \\
\hline Genus Erysipelatoclostridium & $11(55)$ & $8.4 \pm 0.9$ & \\
\hline Clostridium ramosum & $8(40)$ & $8.2 \pm 0.9$ & SAA; ABA; CA; PAB \\
\hline Clostridium innocuum & $8(40)$ & $8.1 \pm 0.43$ & SAA; ABA; CA; PAB \\
\hline Clostridium saccharogumia & $1(5)$ & 8.7 & ABA \\
\hline Clostridium spiroforme & $1(5)$ & 9 & SAA \\
\hline Holdemanella biformis & $1(5)$ & 9.4 & SAA \\
\hline Dielma fastidiosa & $1(5)$ & 8 & SAA; ABA; CA \\
\hline Coprobacillus cateniformis & $1(5)$ & 9 & ABA \\
\hline Absiella dolichum & $1(5)$ & 8 & $\mathrm{CA}$ \\
\hline Turicibacter sanguinis & $1(5)$ & 8 & SAA \\
\hline \multicolumn{4}{|c|}{ Class Clostridia, order Clostridiales } \\
\hline Family Clostridiaceae & $10(50)$ & $8.5 \pm 1.1$ & \\
\hline Genus Clostridium & $4(20)$ & $8.1 \pm 1.4$ & \\
\hline Clostridium perfringens & $3(15)$ & $8.5 \pm 0.7$ & SAA; CA; PAB \\
\hline Clostridium paraputrificum & $2(10)$ & $6.3-9.4$ & SAA; ABA; PAB \\
\hline Clostridium ventriculi & $1(5)$ & 10.4 & ABA \\
\hline Clostridium barattii & $1(5)$ & 6 & PAB \\
\hline Hungatella hathewayi & $7(35)$ & $7.8 \pm 0.8$ & SAA; PAB \\
\hline Mordavella sp. & $1(5)$ & 9 & ABA \\
\hline Lactonifactor sp. ASD3451 & $1(5)$ & 8 & PAB \\
\hline Family Lachnospiraceae & $17(85)$ & $9.0 \pm 1.0$ & \\
\hline Genus Lachnoclostridium & $13(65)$ & $8.4 \pm 1.0$ & \\
\hline Clostridium clostridioforme & $11(55)$ & $8.2 \pm 1.0$ & SAA; ABA; PAB \\
\hline Clostridium scindens & $3(15)$ & $8.0 \pm 0.0$ & SAA; PAB \\
\hline Clostridium symbiosum & $2(10)$ & $6.0-8.0$ & SAA; PAB \\
\hline Lachnoclostridium sp. ASD2032 & $1(5)$ & 9 & SAA \\
\hline Clostridium lavalense & $1(5)$ & 6 & PAB \\
\hline Clostridium hylemonae & $1(5)$ & 9 & SAA \\
\hline Lachnoclostridium sp. ASD3950 & $1(5)$ & 9.3 & ABA \\
\hline Anaerostipes sp. & $8(40)$ & $8.2 \pm 1.0$ & SAA; ABA; CA \\
\hline Eisenbergiella tayi & $2(10)$ & $8.0-9.0$ & $\mathrm{ABA} ; \mathrm{CA}$ \\
\hline Genus Blautia & $13 / 65$ & $8.9 \pm 0.9$ & \\
\hline Blautia torques & $7(35)$ & $8.8 \pm 0.5$ & SAA; ABA; CA \\
\hline Blautia coccoides & $6(30)$ & $7.5 \pm 0.8$ & ABA; PAB \\
\hline Blautia gnavus & $6(30)$ & $8.7 \pm 0.6$ & SAA; ABA; CA \\
\hline Blautia luti & $5(25)$ & $8.5 \pm 0.7$ & SAA; ABA \\
\hline Blautia faecis & $5(25)$ & $8.6 \pm 0.6$ & SAA; CA \\
\hline Blautia obeum & $3(15)$ & $8.5 \pm 0.5$ & SAA; ABA \\
\hline Blautia wexlerae & $2(10)$ & $8.0-9.0$ & ABA; PAB \\
\hline Blautia sp. ASD2945 & $1(5)$ & 8 & ABA \\
\hline Blautia caecimuris & $1(5)$ & 9.6 & $\mathrm{ABA} ; \mathrm{CA}$ \\
\hline Family Ruminococcaceae & $13 / 65$ & $8.8 \pm 0.5$ & \\
\hline Flavonifractor plautii & $7(35)$ & $8.7 \pm 0.5$ & SAA; ABA; PAB \\
\hline Ruthenibacterium lactatiformans & $5(25)$ & $8.5 \pm 0.5$ & $\mathrm{ABA} ; \mathrm{CA}$ \\
\hline Anaerotruncus colihominis & $4(20)$ & $8.3 \pm 0.5$ & $\mathrm{ABA} ; \mathrm{PAB}$ \\
\hline Flavonifractor sp. ASD20665 & $1(5)$ & 7.3 & PAB \\
\hline Monoglobus pectinilyticus & $1(5)$ & 8.3 & SAA \\
\hline Ruminiclostridium leptum & $1(5)$ & 8 & ABA \\
\hline
\end{tabular}




\begin{tabular}{|c|c|c|c|}
\hline Faecalibacterium prausnitzii & $1(5)$ & 8.3 & $\mathrm{ABA}$ \\
\hline Gemmiger formicilis & $1(5)$ & 8 & ABA \\
\hline Agathobaculum sp. ASD2948 & 1 (5) & 8 & ABA \\
\hline Ruminococcaceae ASD2818 & $1(5)$ & 8 & SAA \\
\hline Genus Dorea & $4(20)$ & $8.6 \pm 0.6$ & \\
\hline Dorea longicatena & $3(15)$ & $8.2 \pm 0.3$ & $\mathrm{SAA} ; \mathrm{ABA} ; \mathrm{PAB}$ \\
\hline Dorea formicirans & $1(5)$ & 8 & PAB \\
\hline Dorea sp. & $1(5)$ & 9.3 & ABA \\
\hline Sellimonas intestinalis & $7(35)$ & $8.8 \pm 0.5$ & $\mathrm{SAA} ; \mathrm{ABA}$ \\
\hline Fusicatenibacter saccharivorans & $3(15)$ & $8.4 \pm 0.5$ & $\mathrm{ABA} ; \mathrm{CA}$ \\
\hline Coprococcus comes & $1(5)$ & 8.8 & ABA \\
\hline Family Eubacteriaceae & \multirow{2}{*}{$4(20)$} & \multirow{2}{*}{$7.8 \pm 0.39$} & \multirow{2}{*}{ ABA; PAB } \\
\hline Eubacterium limosum & & & \\
\hline Family Christensenellaceae & \multirow{2}{*}{$1(5)$} & \multirow{2}{*}{9} & \multirow{2}{*}{$\mathrm{CA}$} \\
\hline Christensenella minuta & & & \\
\hline \multicolumn{4}{|c|}{ Family Peptostreptococcaceae } \\
\hline Terrisporobacter sp. & 1 (5) & 8 & PAB \\
\hline Paeniclostridium sordellii & $1(5)$ & 9 & SAA \\
\hline \multicolumn{4}{|c|}{ Genera with uncertain taxonomic position } \\
\hline Intestinimonas sp. & $1(5)$ & 9 & $\mathrm{ABA}$ \\
\hline Lawsonibacter asaccharolyticus & $1(5)$ & 9 & $\mathrm{CA}$ \\
\hline \multicolumn{4}{|c|}{ Class Bacilli } \\
\hline \multicolumn{4}{|c|}{ Order Lactobacillales } \\
\hline \multicolumn{4}{|c|}{ Family Lactobacillaceae } \\
\hline Genus Lactobacillus & $13 / 65$ & $6.3 \pm 1.6$ & \\
\hline Lactobacillus casei/paracasei & $6(30)$ & $6.3 \pm 1.9$ & MRS \\
\hline Lactobacillus gasseri/acidophilus & $5(20)$ & $7.0 \pm 1.2$ & MRS \\
\hline Lactobacillus rhamnosus & $3(15)$ & $4.5 \pm 0.2$ & MRS \\
\hline Lactobacillus salivarius/delbruekii & $2(10)$ & $5.5-6.3$ & MRS \\
\hline Lactobacillus fermentum & $1(5)$ & 4 & MRS \\
\hline Lactobacillus brevis & $1(5)$ & 4 & MRS \\
\hline Family Leuconostocaceae & \multirow{2}{*}{$1(5)$} & \multirow{2}{*}{6.3} & \multirow{2}{*}{ MRS } \\
\hline Leuconostoc lactis & & & \\
\hline \multicolumn{4}{|c|}{ Family Enterococcaceae } \\
\hline Genus Enterococcus & $16 / 80$ & $6.1 \pm 1.3$ & \\
\hline Enterococcus faecalis & $8(40)$ & $5.8 \pm 1.0$ & mEA \\
\hline Enterococcus faecium & $9(45)$ & $4.9 \pm 0.7$ & mEA \\
\hline Enterococcus durans & $3(15)$ & $4.3 ; 4.8 ; 9.5$ & mEA \\
\hline Enterococcus avium/raffinosus & $7(35)$ & $6.5 \pm 0.8$ & mEA \\
\hline Enterococcus casseliflavus & $1(5)$ & 6 & mEA \\
\hline Enterococcus gallinarum & $1(5)$ & 4 & mEA \\
\hline \multicolumn{4}{|c|}{ Family Streptococcaceae } \\
\hline Genus Streptococcus & $19 / 95$ & $7.5 \pm 1.2$ & \\
\hline Streptococcus salivarius & $17 / 85$ & $6.9 \pm 1.2$ & mEA. MRS \\
\hline Streptococcus parasanguinis & $9(45)$ & $6.6 \pm 1.0$ & mEA. MRS \\
\hline Streptococcus oralis/pneumoniae/mitis & $5(45)$ & $7.1 \pm 2.6$ & mEA. MRS \\
\hline Streptococcus anginosus & $2(10)$ & $5.0-5.7$ & mEA. MRS \\
\hline Streptococcus mutans & $2(10)$ & $6.1-6.3$ & mEA. MRS \\
\hline Streptococcus constellatus & $1(5)$ & 6 & MRS \\
\hline Streptococcus infantarius & $1(5)$ & 8.4 & MRS \\
\hline Streptococcus disgalactiae & $1(5)$ & 8.9 & $\mathrm{CA}$ \\
\hline Genus Lactococcus & \multirow{2}{*}{$1(5)$} & \multirow{2}{*}{6.1} & \multirow{2}{*}{ MRS } \\
\hline Lactococcus lactis & & & \\
\hline
\end{tabular}




\begin{tabular}{|c|c|c|c|}
\hline Family Aerococcaceae & \multirow{2}{*}{$1(5)$} & \multirow{2}{*}{6} & \multirow{2}{*}{ SAA } \\
\hline Aerococcus viridans & & & \\
\hline \multicolumn{4}{|c|}{ Order Bacillales } \\
\hline Family Staphylococcaceae & $18 / 90$ & $5.0 \pm 1.7$ & \\
\hline Staphylococcus aureus & $14 / 70$ & $3.9 \pm 0.8$ & GMSA \\
\hline Staphylococcus epidermidis & $6(30)$ & $4.3 \pm 1.4$ & GMSA \\
\hline Staphylococcus hominis & $3(15)$ & $4.6 \pm 0.8$ & GMSA \\
\hline Staphylococcus haemolyticus & $3(15)$ & $2.5-5.2$ & GMSA \\
\hline Staphylococcus sacharolyticus & $2(10)$ & 9 & ABA \\
\hline Staphylococcus warneri & $2(10)$ & $5.2-8.8$ & GMSA; CA \\
\hline Staphylococcus capitis & $1(5)$ & 4.3 & GMSA \\
\hline Staphylococcus gallinarum & $1(5)$ & 3.2 & GMSA \\
\hline Family Bacillaceae & \multirow{2}{*}{$6(30)$} & \multirow{2}{*}{$3.4 \pm 0.3$} & \multirow{2}{*}{ GMSA } \\
\hline Bacillus sp. & & & \\
\hline \multicolumn{4}{|c|}{ Class Negativicutes } \\
\hline Order Veillonellales & \multirow{2}{*}{$12(60)$} & \multirow{2}{*}{$8.8 \pm 0.9$} & \\
\hline Family Veillonellaceae & & & \\
\hline Veilonella sp. & $7(35)$ & $8.0 \pm 0.9$ & SAA; ABA; CA \\
\hline Allisonella histaminiformans & $1(5)$ & 8 & ABA \\
\hline Genus Dialister & $9(45)$ & $9.0 \pm 0.5$ & \\
\hline Dialister invisus & $8(40)$ & $9.1 \pm 0.4$ & SAA; ABA \\
\hline Dialister succinatiphilus & $1(5)$ & 8 & $\mathrm{CA}$ \\
\hline \multicolumn{4}{|c|}{ Order Selenomonadales, family Selenomonadacea } \\
\hline Megamonas sp. & $2(10)$ & $8.8-9.0$ & ABA; CA \\
\hline \multicolumn{4}{|c|}{ Order Acidaminococcales, family Acidaminococcaceae } \\
\hline Phascolarctobacterium faecium & $8(40)$ & $9.0 \pm 0.4$ & $\mathrm{SAA} ; \mathrm{ABA} ; \mathrm{CA}$ \\
\hline Phascolarctobacterium succinatutens & $1(5)$ & 8 & SAA \\
\hline
\end{tabular}

which could not be established are listed in the Table 6. Most of them (7 of 10 strains) belonged to the phylum Firmicutes. Four of them had a phylogenetic relationship with species from the genera Blautia, Flintibacter and Lachnoclostridium of the family Lachnospiraceae. Two clones were close to different species of the family Ruminococcaceae, and another clone was phylogenetically similar to members of the genus Lactonifractor of the family Clostridiaceae. In addition, one clone of the new bacterial taxon was associated with a typical strain belonging to the family Sutterellaceae, included in the Proteobacteria phylum, and one clone belonged to the genera Parabacteroides and Bacteroides (families Porphyromonadaceae and Bacteroidaceae respectively, phylum Bacteroidetes).

\section{DISCUSSION}

This age group of children was chosen for the study because earlier it was shown that the qualitative and quantitative parameters of the gut microbiota by the age of three years become close to the typical adults values [17]. By this age, the gut microbiota acquires relative compositional stability and does not change significantly over time [18].

The main problems regarding the culture-based methods are associated with the selection of growth media, which provide the growth of fastidious strictly anaerobic bacteria, and with the further identification of numerous strains of microorganisms growing on these media. In our study we used well-known growth media including media for the strictly anaerobic bacteria. After inoculation of media Petri dishes were incubated at $37^{\circ} \mathrm{C}$ in the anaerobic jars.
It was previously shown that increase the number of growth media and the number of samples leads to isolation of a large number of bacterial species, which indicates significant individual differences in the composition of the human gut microbiota [3]. This is confirmed by the results of metagenomic sequencing, which revealed a very high variability in abundance (12-2,200 times) for the 57 most common human bacterial species [19]. In our study, though an average of $34 \pm 8$ species of microorganisms was isolated from each child, in total, 159 species of bacteria were found in all children, including new taxa.

The greatest species diversity (more than 90 species of bacteria) was found in the phylum Firmicutes, with more than half of them belonging to the class Clostridia of the order Clostridiales. The dominating by frequency of occurrence and quantitative content families of this class were Lachnospiraceae and Ruminococcaceae. The obtained data characterizing the composition of this part of microbiota in Russian children correspond with the results of previous studies, in which both culture-based methods and the analysis of the nucleotide sequences of the libraries of $16 \mathrm{~S}$ rDNA genes established the dominance of these taxa in human gut microbiota $[6,20]$.

Among the representatives of intestinal endosymbionts, which belong to the classes Erysipelotrichia and Clostridia isolated in pure culture from feces of healthy children the bacteria associated with various infectious diseases were also present. Therefore, the improvement of the culture methods and species identification for the bacteria of these taxa has not only ecological but also clinical significance. For example, Clostridium innocuum is often associated with bacteriemia in 
Table 3. Species identity of the Bacteroidetes phylum cultured bacteria of the gastrointestinal tract microflora isolated from healthy children $(n=20)$

\begin{tabular}{|c|c|c|c|}
\hline \multicolumn{4}{|c|}{ Phylum Bacteroidetes, class Bacteroidia, order Bacteroidales } \\
\hline Taxa & Observed number (\%) & Mean $\pm S D \log _{10} C F U / g$ & Growth media \\
\hline Family Bacteroidaceae & $20(100)$ & $10.1 \pm 0.4$ & \\
\hline Bacteroides dorei/vulgatus & 19 (95) & $9.5 \pm 0.5$ & SAA; ABA; CA \\
\hline Bacteroides ovatus/xylanisolvens & $16(80)$ & $9.2 \pm 0.5$ & SAA; ABA; CA \\
\hline Bacteroides uniformis & $17(85)$ & $9.4 \pm 0.5$ & SAA; ABA; CA \\
\hline Bacteroides fragilis & $9(45)$ & $9.1 \pm 0.6$ & SAA; ABA; CA \\
\hline Bacteroides thetaiotaomicron & $9(45)$ & $9.1 \pm 0.5$ & SAA; ABA; CA \\
\hline Bacteroides caccae & $8(40)$ & $9.0 \pm 0.7$ & SAA; ABA; CA \\
\hline Bacteroides eggerthii & $6(30)$ & $9.2 \pm 0.5$ & SAA; ABA; CA \\
\hline Bacteroides stercoris & $4(20)$ & $9.0 \pm 0.2$ & SAA; ABA; CA \\
\hline Bacteroides intestinalis & $3(15)$ & $9.2 \pm 0.3$ & SAA; ABA; CA \\
\hline Bacteroides clarus & $2(10)$ & $9.0-10.3$ & ABA \\
\hline Bacteroides massiliensis & $2(10)$ & $9.3-9.5$ & SAA; ABA; CA \\
\hline Bacteroides plebeius & $1(5)$ & 9.6 & SAA; ABA; CA \\
\hline Bacteroides coprocola & $1(5)$ & 8 & $A B A$ \\
\hline Bacteroides salyersiae & $1(5)$ & 8 & $\mathrm{CA}$ \\
\hline Bacteroides sp. ASD2038 & 1 (5) & 9.7 & SAA \\
\hline Family Rikenellaceae & $18 / 90$ & $9.5 \pm 0.4$ & \\
\hline Alistipes onderdonkii & $11(55)$ & $9.1 \pm 0.5$ & SAA; ABA; CA \\
\hline Alistipes putredinis & $10(50)$ & $9.5 \pm 0.5$ & SAA; ABA; CA \\
\hline Alistipes finigoldii & $8(40)$ & $8.8 \pm 0.7$ & SAA; ABA; CA \\
\hline Alistipes shachii & $5(25)$ & $9.2 \pm 0.3$ & SAA; ABA; CA \\
\hline Alistipes indistinctus & $2(10)$ & $8.0-9.0$ & $\mathrm{CA}$ \\
\hline Alistipes obessii & $3(15)$ & $9.1 \pm 0.2$ & ABA \\
\hline Alistipes inops & $3(15)$ & $8.8 \pm 0.7$ & SAA; ABA \\
\hline Alistipes massiliensis & $1(5)$ & 8.8 & $\mathrm{ABA} ; \mathrm{CA}$ \\
\hline Alistipes ihumii & 1 (5) & 9.4 & SAA; ABA \\
\hline Family Porphyromonadaceae & $15(75)$ & $9.4 \pm 0.5$ & \\
\hline Genus Parabacteroides & $13(65)$ & $9.2 \pm 0.7$ & \\
\hline Parabacteroides distasonis & $9(45)$ & $9.1 \pm 0.8$ & SAA; ABA; CA \\
\hline Parabacteroides merdae & $7(35)$ & $8.9 \pm 0.7$ & SAA; ABA; CA \\
\hline Parabacteroides sp. ASD2049 & 1 (5) & 9 & SAA \\
\hline Barnesiella intestinihominis & $8(40)$ & $9.2 \pm 0.3$ & SAA; ABA; CA \\
\hline Coprobacter fastidiosus & $3(15)$ & $9.1 \pm 0.1$ & SAA; ABA; CA \\
\hline Family Odoribacteraceae & $8(40)$ & $9.3 \pm 0.3$ & \\
\hline Odoribacter splanchnicus & $5(25)$ & $9.3 \pm 0.3$ & SAA; ABA; CA \\
\hline Butyricimonas sp. & $4(20)$ & $9.3 \pm 0.4$ & $\mathrm{ABA} ; \mathrm{CA}$ \\
\hline Family Prevotellaceae & $3(15)$ & $8.8 \pm 0.9$ & \\
\hline Prevotella copri & $2(10)$ & $8.5-9.0$ & SAA; ABA; CA \\
\hline Prevotella melaninogenica & $1(5)$ & 8 & $\mathrm{ABA}$ \\
\hline Prevotella rara & $1(5)$ & 9 & $\mathrm{ABA} ; \mathrm{CA}$ \\
\hline Paraprevotella clara & $1(5)$ & 9.6 & $\mathrm{ABA} ; \mathrm{CA}$ \\
\hline
\end{tabular}

patients with immunodeficiency. It is resistant to antibacterial drugs used for treatment of anaerobic infections. C. ramosum, which were also isolated, are considered the second most common bacteria from the clostridium group after $C$. perfringens, causing abscesses, peritonitis, bacteriemia and chronic otitis media in children, and the third most common type of clostridia causing bacteriemia in adults [21, 22].

The Bacteroidetes phylum made up the second group by the number of identified taxa after Firmicutes and was represented by 33 species of bacteria belonging, however, to only one order Bacteroidales.

It is known that Bacteroidales includes the main part of anaerobic nonsporeforming gram-negative rod-shaped bacteria that colonize the human gastrointestinal tract [23]. We found, that in the group of children under study representatives of the Bacteroidaceae, Rikenellaceae and Porphyromonadaceae families dominated and were isolated from 100\%, 90\% and $75 \%$ of children respectively. In our previous study, to assess 
Table 4. Species identity of the Proteobacteria phylum cultured bacteria of the gastrointestinal tract microflora isolated from healthy children $(n=20)$

\begin{tabular}{|c|c|c|c|}
\hline \multicolumn{4}{|c|}{ Phylum Proteobacteria } \\
\hline \multicolumn{4}{|c|}{ Class Gammaproteobacteria } \\
\hline Taxa & Observed number $(\%)$ & Mean $\pm S D \log _{10} \mathrm{CFU} / \mathrm{g}$ & Growth media \\
\hline \multicolumn{4}{|c|}{ Order Enterobacteriales, family Enterobacteriaceae } \\
\hline Escherichia coli & $20(100)$ & $7.2 \pm 1.4$ & $\mathrm{EA} ; \mathrm{CAa}$ \\
\hline Enterobacter cloacae & $6(30)$ & $6.0 \pm 1.5$ & $\mathrm{EA} ; \mathrm{SSA} ; \mathrm{CAa}$ \\
\hline Citrobacter freundii & $4(20)$ & $5.8 \pm 0.68$ & $\mathrm{EA} ; \mathrm{SSA} ; \mathrm{CAa}$ \\
\hline Klebsiella pneumonia & $4(20)$ & $6.5 \pm 1.7$ & $\mathrm{EA} ; \mathrm{CAa}$ \\
\hline Leclercia adecarboxylata & $1(5)$ & 6.5 & $\mathrm{CAa}$ \\
\hline Proteus mirabilis & $1(5)$ & 6 & SSA; CAa \\
\hline \multicolumn{4}{|c|}{ Class Betaproteobacteria, order Burkholderiales } \\
\hline Family Sutterellaceae & $12(60)$ & $8.8 \pm 0.4$ & \\
\hline Parasutterella excrementihominis & $4(20)$ & $8.6 \pm 0.4$ & $\mathrm{ABA} ; \mathrm{CA}$ \\
\hline Sutterella wadsworthensis & $5(25)$ & $8.9 \pm 0.1$ & ABA \\
\hline Sutterella massiliensis & 1 (5) & 9.5 & CA \\
\hline Sutterella sp. ASD3426 & 1 (5) & 8 & CA \\
\hline Duodenibacillus massiliensis & 1 (5) & 9.1 & SAA \\
\hline Family Oxalobacteraceae & \multirow{2}{*}{$1(5)$} & \multirow{2}{*}{8} & \multirow{2}{*}{$\mathrm{CA}$} \\
\hline Massilia timonae & & & \\
\hline \multicolumn{4}{|c|}{ Class Deltaproteobacteria } \\
\hline \multicolumn{4}{|c|}{ Order Desulfovibrionales, family Desulfovibrionaceae } \\
\hline Bilophila wadsworthia & $11(55)$ & $8.0 \pm 0.8$ & SAA; CA; PAB \\
\hline Desulfovibrio piger & $1(5)$ & 8.1 & PAB \\
\hline
\end{tabular}

the composition of the dominant groups of intestinal bacteria belonging to the Bacteroidales order in 6 years old children, we inoculated serial dilutions of feces only on Columbia Blood Agar with the addition of sheep blood followed by determining the species of anaerobic gram-negative rod-shaped bacteria using the restriction analysis of amplified fragments of the $16 \mathrm{~S}$ rRNA gene (ARDRA), as well as their sequencing.

In that study, we isolated only 38 strains of bacteria belonging to 13 species of Bacteroidales from 8 children [12]. In the present study, we used 3 different growth media to identify the same group of bacteria, with preliminary identification of all the grown bacteria using mass spectrometry and additional 16S rDNA gene sequencing for strains with an unclear taxonomic position. This approach allowed us to distinguish 33 species of bacteria belonging to 9 genera and 5 families of the order Bacteroidales in addition to bacteria belonging to other taxonomic groups.

Bacteria of Prevotellaceae family, also belonging to the order Bacteroidales, were found only in three children (15\%). In spite of the fact that about 30 prevotella's species are known to date, as bacteria colonizing mainly the human oral cavity, until recently only 2 species $P$. copri and $P$. stercorea were considered commensals of the gastrointestinal tract. In our study in addition to $P$. copri the bacteria from species $P$. melaninogenica, which are rarely isolated from the intestine, and recently described new species $P$. rara were isolated from a child for the first time [24].

As predominant groups of intestinal bacteria, prevotella is most often determined in people whose diet is based on the products of plant origin, which is associated with the ability of these bacteria to degrade plant polysaccharides in the distal intestinal tract [20]. On the other hand, the prevalence in the gut microbiota the bacteria of the Bacteroides genus and the Clostridiales order, as shown in our study, had been previously associated with a mixed diet characterized by the inclusion in diet both animal and vegetable products along with easily digestible carbohydrates $[25,26]$.

\section{CONCLUSIONS}

The approach we used, based on the use of a wide range of growth media for the isolation of difficult-to-cultivate groups of intestinal endosymbionts, both under aerobic and anaerobic conditions, followed by the bacteria species identification by the MALDI TOF mass spectrometry and the 16S rRNA gene sequencing, allowed us to analyze the qualitative and quantitative composition of the dominant cultivated groups of gut microbiota in children. In general, the results describing the taxonomic composition of the fecal microbiota of children obtained by the culture-based method do not contradict the data obtained by molecular methods based on the sequencing of bacterial DNA. In addition, we have isolated in pure culture the numerous strains of difficult-to-cultivate bacteria and 10 strains of new bacteria with not yet studied biological properties. The data obtained allow us to expand our understanding of the spectrum of cultivated taxonomic groups of colon bacteria and their quantitative content in children. The strains we isolated, both belonging to known and new taxa, can be used to study a wide repertoire of their properties, including their biotherapeutic potential for creating the new probiotic medications. At the same time, many wellknown taxa of gut microbiota, including representatives of such dominant genera as Faecalibacterium and Roseburia, we were unable to isolate, which indicates the need to use 
Table 5. Species identity of the Saccharomycetales order fungi isolated from healthy children $(n=20)$

\begin{tabular}{|c|c|c|c|}
\hline Fungi taxa & Observed number (\%) & Mean \pm SD $\log _{10}$ CFU/g & Growth media \\
\hline Order Saccharomycetales & $9(45)$ & $3.4 \pm 1.4$ & \\
\hline Family Debaryomycetaceae & $7(35)$ & $3.5 \pm 1.4$ & \\
\hline Candida albicans & $5(25)$ & $3.7 \pm 1.4$ & $S C 2 A$ \\
\hline Candida parapsilosis & $1(5)$ & 2.5 & $S C 2 A$ \\
\hline Candida sp. & $1(5)$ & 2.5 & $\mathrm{SC} 2 \mathrm{~A}$ \\
\hline Family Metschnikowiaceae & \multirow{2}{*}{$2(10)$} & \multirow{2}{*}{$2.0-5.0$} & \multirow{2}{*}{ SC2A } \\
\hline Clavispora lusitaniae & & & \\
\hline
\end{tabular}

Table 6. New gastrointestinal tract bacteria phylotypes isolated from healthy children and the values of the nucleotide sequences of their $16 \mathrm{~S}$ rDNA levels of homology with the same sequences of typical strains of the most closely related validated species in accordance with the International Code of Nomenclature of Bacteria (Bacteriological Code)

\begin{tabular}{|c|c|c|c|c|c|}
\hline № & $\begin{array}{l}\text { Strain } \\
\text { number }\end{array}$ & Phylum/family & $\begin{array}{l}\text { № of sequencing in the } \\
\text { GenBank database }\end{array}$ & $\begin{array}{l}\text { Related strains with high level of sequence similarity } \\
\text { (megablast algorithm) in the GenBank database }\end{array}$ & $\begin{array}{l}\text { Homology } \\
\text { (\%) }\end{array}$ \\
\hline 1 & ASD 3426 & $\begin{array}{l}\text { Proteobacteria } \\
\text { Sutterellaceae }\end{array}$ & MK615133.1 & Sutterella wadsworthensis WAL9799 & 97.93 \\
\hline 2 & ASD2049 & $\begin{array}{l}\text { Bacteroidetes } \\
\text { Porphyromonadaceae }\end{array}$ & MG321612.1 & Parabacteroides merdae JCM9497 & 96.63 \\
\hline 3 & ASD2038 & $\begin{array}{l}\text { Bacteroidetes } \\
\text { Bacteroidaceae }\end{array}$ & MK615124.1 & Bacteroides ovatus ATCC 8483 & 98.19 \\
\hline 4 & ASD2032 & $\begin{array}{l}\text { Firmicutes } \\
\text { Lachnospiraceae }\end{array}$ & MK615123.1 & [Clostridium] amygdalinum BR-10 & 95.72 \\
\hline 5 & ASD2945 & $\begin{array}{l}\text { Firmicutes } \\
\text { Lachnospiraceae }\end{array}$ & MK615128.1 & Blautia faecis KB1 & 96.03 \\
\hline 6 & ASD3950 & $\begin{array}{l}\text { Firmicutes } \\
\text { Lachnospiraceae }\end{array}$ & MK615131.1 & [Clostridium] glycyrrhizinilyticum ZM35 & 95.73 \\
\hline 7 & ASD3451 & $\begin{array}{l}\text { Firmicutes } \\
\text { Clostridiaceae }\end{array}$ & MK615130.1 & Lactonifactor longoviformis ED-Mt61/PYG-s6 & 94.61 \\
\hline 8 & ASD20665 & $\begin{array}{l}\text { Firmicutes } \\
\text { Ruminococcaceae }\end{array}$ & MK615126.1 & Flintibacter butyricus BLS21 & 97.33 \\
\hline 9 & ASD2818 & $\begin{array}{l}\text { Firmicutes } \\
\text { Ruminococcaceae }\end{array}$ & MH043116.1 & Caproiciproducens galactitolivorans BS-1 & 93.76 \\
\hline 10 & ASD2948 & $\begin{array}{l}\text { Firmicutes } \\
\text { Ruminococcaceae }\end{array}$ & MK615129.1 & Agathobaculum desmolans ATCC43058 & 97.01 \\
\hline
\end{tabular}

more advanced anaerobic technologies in such studies, in particular, anaerobic glove box at the stages of sample preparation, inoculation and grown culture counting. The complexity and labor input of the culture-based method do not allow recommend it for the routine use in clinical practice, even assuming that in the future all stages of the study would be fully automated. However, the development of methods of isolation and identification of strictly anaerobic colon bacteria is necessary, since these bacteria can have pathobiotic potential and occur in clinical material (wound discharge, biopsy specimens, blood, liquor, etc.), in which the usual quantitative content of the species of bacteria is not so great.

\section{References}

1. Mailhe M, Ricaboni D, Vitton V, Gonzalez JM, Bachar D, Dubourg G, et al. Repertoire of the gut microbiota from stomach to colon using culturomics and next-generation sequencing. BMC Microbiol. 2018; (18): 157.

2. Atanu $A$, Mojibur RK. An insight into gut microbiota and its functionalities. Cellular and Molecular Life Sciences. 2019; (76): 473-93.

3. Hayashi H, Sakamoto M, Benno Y. Phylogenetic analysis of the human gut microbiota using 16S rDNA clone libraries and strictly anaerobic culture-based methods. Microbiol Immunol. 2002; 46 (8): 535-48.

4. Lagier J-C, Khelaifia S, Alou MT, Ndongo S, Dione N, Hugon P, et al. Culture of previously uncultured members of the human gut microbiota by culturomics. Nature Microbiology. 2016; (1): 16203.

5. Shkoporov AN, Hill C. Bacteriophages of the Human Gut: The "Known Unknown" of the Microbiome. Cell Host Microbe. 2019; 25 (2): 195-209.

6. Vandeputte D, Kathagen G, D'hoe K, Vieira-Silva S, Valles-
Colomer M, Sabino J, et al. Quantitative microbiome profiling links gut community variation to microbial load. Nature. 2017; (551): $507-11$.

7. Tanoue T, Morita S, Plichta DR. A defined commensal consortium elicits CD8 T cells and anti-cancer immunity. Nature. 2019; (565): 600-05.

8. Shkoporov AN, Efimov BA, Khokhlova EV, Chernaia ZA, Postnikova EA, Belkova MD. Effect of probiotic Lactobacillus and Bifidobacterium cultures on intestinal microbiota composition in healthy adults. Tekhnika i Tekhnologiya Pishchevykh Proizvodstv. 2014; (1): 126-30. Russian.

9. Lagier JC, Dubourg G, Million M, Cadoret F, Bilen M, Fenollar F, et al. Culturing the human microbiota and culturomics. Nat Rev Microbiol. 2018; (1): 540-50.

10. Rychert J, Burnham CA, Bythrow M, Garner OB, Ginocchio CC, Jennemann R, et al. Multicenter evaluation of the Vitek MS matrix-assisted laser desorption ionization-time of flight mass spectrometry system for identification of Gram-positive aerobic 
bacteria. J Clin Microbiol. 2013; 51 (7): 2225-31.

11. McMullen AR, Wallace MA, Pincus DH, Wilkey K, Burnham CA. Evaluation of the Vitek MS matrix-assisted laser desorption ionization-time of flight mass spectrometry system for identification of clinically relevant filamentous fungi. J Clin Microbiol. 2016; (54): 2068-73.

12. Shkoporov AN, Khokhlova EV, Kulagina EV, Smeianov WV, Kafarskaia LI, Efimov BA. Application of several molecular techniques to study numerically predominant Bifidobacterium spp. and Bacteroidales order strains in the feces of healthy children. Biosci Biotechnol Biochem. 2008; 72 (3): 742-8.

13. Chaplin AV, Brzhozovskii AG, Parfenova TV, Kafarskaia LI, Volodin NN, Shkoporov AN, et al. Species Diversity of Bifidobacteria in the Intestinal Microbiota Studied Using MALDI-TOF Mass-Spectrometry. Vestn Ross Akad Med Nauk. 2015; 70 (4): 435-40. Russian.

14. Stackebrandt E, Ebers J. Taxonomic parameters revisited: tarnished gold standards. Microbiol Today. 2006; (8): 6-9.

15. Bezdek JC, Hathaway RJ. VAT: A Tool for Visual Assessment of Cluster Tendency. In: Proceedings of the 2002 International Joint Conference Neural Networks. 2002; (3): 2225-30.

16. Fitzgerald CB, Shkoporov AN, Sutton TDS, Chaplin AV, Velayudhan V, Ross RP, et al. Comparative analysis of Faecalibacterium prausnitzii genomes shows a high level of genome plasticity and warrants separation into new species-level taxa. BMC Genomics. 2018; 19 (1): 931.

17. Yatsunenko T, Rey FE, Manary MJ, Trehan I, Dominguez-Bello MG, Contreras $\mathrm{M}$, et al. Human gut microbiome viewed across age and geography. Nature. 2012; 486 (7402): 222-7.

18. De Meij TGJ, Budding AE, De Groot EFJ, Jansen FM,

\section{Литература}

1. Mailhe M, Ricaboni D, Vitton V, Gonzalez JM, Bachar D, Dubourg G, et al. Repertoire of the gut microbiota from stomach to colon using culturomics and next-generation sequencing. BMC Microbiol. 2018; (18): 157

2. Atanu A, Mojibur RK. An insight into gut microbiota and its functionalities. Cellular and Molecular Life Sciences. 2019; (76): 473-93.

3. Hayashi H, Sakamoto M, Benno Y. Phylogenetic analysis of the human gut microbiota using 165 rDNA clone libraries and strictly anaerobic culture-based methods. Microbiol Immunol. 2002; 46 (8): 535-48

4. Lagier J-C, Khelaifia S, Alou MT, Ndongo S, Dione N, Hugon P, et al. Culture of previously uncultured members of the human gut microbiota by culturomics. Nature Microbiology. 2016; (1): 16203.

5. Shkoporov AN, Hill C. Bacteriophages of the Human Gut: The "Known Unknown" of the Microbiome. Cell Host Microbe. 2019; 25 (2): 195-209.

6. Vandeputte D, Kathagen G, D'hoe K, Vieira-Silva S, Valles-Colomer M, Sabino J, et al. Quantitative microbiome profiling links gut community variation to microbial load. Nature. 2017; (551): 507-11.

7. Tanoue T, Morita S, Plichta DR. A defined commensal consortium elicits CD8 T cells and anti-cancer immunity. Nature. 2019; (565): 600-05.

8. Шкопоров А. Н., Ефимов Б. А., Хохлова Е. В., Черная 3. А., Постникова Е. А., Белкова М. Д. Влияние приема пробиотических бактерий рода Lactobacillus и Bifidobacterium на состав микрофлоры кишечника у здоровых людей. Техника и технология пищевых производств. 2014; (1): 126-30.

9. Lagier JC, Dubourg G, Million M, Cadoret F, Bilen M, Fenollar F, et al. Culturing the human microbiota and culturomics. Nat Rev Microbiol. 2018; (1): 540-50.

10. Rychert J, Burnham CA, Bythrow M, Garner OB, Ginocchio CC, Jennemann $R$, et al. Multicenter evaluation of the Vitek MS matrix-assisted laser desorption ionization-time of flight mass spectrometry system for identification of Gram-positive aerobic bacteria. J Clin Microbiol. 2013; 51 (7): 2225-31.

11. McMullen AR, Wallace MA, Pincus DH, Wilkey K, Burnham CA. Evaluation of the Vitek MS matrix-assisted laser desorption ionization-time of flight mass spectrometry system for identification of clinically relevant filamentous fungi. J Clin Microbiol. 2016; (54):
Kneepkens CMF, Benninga MA, et al. Composition and stability of intestinal microbiota of healthy children within a Dutch population. FASEB J. 2016; 30 (4): 1512-22.

19. Qin J, Li R, Raes J, Arumugam M, Burgdorf KS, Manichanh C, et al. MetaHIT Consortium A human gut microbial gene catalogue established by metagenomic sequencing. Nature. 2010; (464): 59-65.

20. Browne HP, Forster SC, Anonye BO. Culturing of 'unculturable' human microbiota reveals novel taxa and extensive sporulation. Nature. 2016; 533 (7604): 543-6.

21. Brook I. Clostridial Infections in Children: Spectrum and Management. Curr Infect Dis Rep. 2015; (17): 47.

22. Chia JH, Feng $Y$, Su LH, Wu TL, Chen $C L$, Liang $Y H$, et al. Clostridium innocuum is a significant vancomycin-resistant pathogen for extraintestinal clostridial infection Clinical Microbiology and Infection. 2017; (23): 560-6.

23. The Human Microbiome Project Consortium. Structure, function and diversity of the healthy human microbiome. Nature. 2012; 486 (7402): 207-14.

24. Efimov BA, Chaplin AV, Shcherbakova VA, Suzina NE, Podoprigora IV, Shkoporov AN. Prevotella rara sp. nov., isolated from human faeces. Int J Syst Evol Microbiol. 2018; 68 (12): 3818-25.

25. Shankar V, Gouda M, Moncivaiz J, Gordon A, Reo NV, Hussein L, et al. Differences in Gut Metabolites and Microbial Composition and Functions between Egyptian and U.S. Children Are Consistent with Their Diets. mSystems. 2017; 2 (1): e00169-16.

26. Arumugam M, Raes J, Pelletier E, Le Paslier D, Yamada T, Mende DR, et al. Enterotypes of the human gut microbiome. Nature. 2011; 473 (7346): 174-80.

\section{8-73}

12. Shkoporov AN, Khokhlova EV, Kulagina EV, Smeianov VV, Kafarskaia LI, Efimov BA. Application of several molecular techniques to study numerically predominant Bifidobacterium spp. and Bacteroidales order strains in the feces of healthy children. Biosci Biotechnol Biochem. 2008; 72 (3): 742-8.

13. Чаплин А. В., Бржозовский А. Г., Парфёнова Т. В., Кафарская Л. И., Володин Н. Н., Шкопоров А. Н. и др. Изучение видового разнообразия бактерий рода Bifidobacterium кишечной микросрлоры с использованием метода MALDI-TOF массспектрометрии. Вестник РАМН. 2015; 70 (4): 435-40.

14. Stackebrandt E, Ebers J. Taxonomic parameters revisited: tarnished gold standards. Microbiol Today. 2006; (8): 6-9.

15. Bezdek JC, Hathaway RJ. VAT: A Tool for Visual Assessment of Cluster Tendency. In: Proceedings of the 2002 International Joint Conference Neural Networks. 2002; (3): 2225-30.

16. Fitzgerald CB, Shkoporov AN, Sutton TDS, Chaplin AV, Velayudhan V, Ross RP, et al. Comparative analysis of Faecalibacterium prausnitzii genomes shows a high level of genome plasticity and warrants separation into new species-level taxa. BMC Genomics. 2018; 19 (1): 931.

17. Yatsunenko T, Rey FE, Manary MJ, Trehan I, Dominguez-Bello MG, Contreras $\mathrm{M}$, et al. Human gut microbiome viewed across age and geography. Nature. 2012; 486 (7402): 222-7.

18. De Meij TGJ, Budding AE, De Groot EFJ, Jansen FM, Kneepkens CMF, Benninga MA, et al. Composition and stability of intestinal microbiota of healthy children within a Dutch population. FASEB J. 2016; 30 (4): 1512-22.

19. Qin J, Li R, Raes J, Arumugam M, Burgdorf KS, Manichanh C, et al. MetaHIT Consortium A human gut microbial gene catalogue established by metagenomic sequencing. Nature. 2010; (464): 59-65.

20. Browne HP, Forster SC, Anonye BO. Culturing of 'unculturable' human microbiota reveals novel taxa and extensive sporulation. Nature. 2016; 533 (7604): 543-6.

21. Brook I. Clostridial Infections in Children: Spectrum and Management. Curr Infect Dis Rep. 2015; (17): 47.

22. Chia JH, Feng Y, Su LH, Wu TL, Chen CL, Liang Y-H, et al. Clostridium innocuum is a significant vancomycin-resistant pathogen for extraintestinal clostridial infection Clinical Microbiology and Infection. 
2017; (23): 560-6

23. The Human Microbiome Project Consortium. Structure, function and diversity of the healthy human microbiome. Nature. 2012 486 (7402): 207-14.

24. Efimov BA, Chaplin AV, Shcherbakova VA, Suzina NE, Podoprigora IV, Shkoporov AN. Prevotella rara sp. nov., isolated from human faeces. Int J Syst Evol Microbiol. 2018; 68 (12): 3818-25.
25. Shankar V, Gouda M, Moncivaiz J, Gordon A, Reo NV, Hussein L, et al. Differences in Gut Metabolites and Microbial Composition and Functions between Egyptian and U.S. Children Are Consistent with Their Diets. mSystems. 2017; 2 (1): e00169-16.

26. Arumugam M, Raes J, Pelletier E, Le Paslier D, Yamada T, Mende DR, et al. Enterotypes of the human gut microbiome. Nature. 2011; 473 (7346): 174-80. 